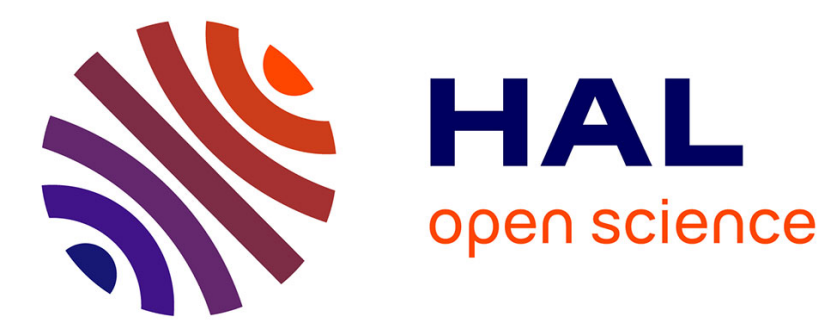

\title{
THE DEVELOPMENT OF THE WATER MANAGEMENT SYSTEM OF ANGKOR: A PROVISIONAL MODEL
}

Roland Fletcher, Christophe Pottier, Damian Evans, Matti Kummu

\section{- To cite this version:}

Roland Fletcher, Christophe Pottier, Damian Evans, Matti Kummu. THE DEVELOPMENT OF THE WATER MANAGEMENT SYSTEM OF ANGKOR: A PROVISIONAL MODEL. BIPPA Bulletin of the Indo-Pacific Prehistory Association , 2008, 28, pp.57-66. hal-03026457

\section{HAL Id: hal-03026457 https://hal.science/hal-03026457}

Submitted on 26 Nov 2020

HAL is a multi-disciplinary open access archive for the deposit and dissemination of scientific research documents, whether they are published or not. The documents may come from teaching and research institutions in France or abroad, or from public or private research centers.
L'archive ouverte pluridisciplinaire HAL, est destinée au dépôt et à la diffusion de documents scientifiques de niveau recherche, publiés ou non, émanant des établissements d'enseignement et de recherche français ou étrangers, des laboratoires publics ou privés. 


\title{
THE DEVELOPMENT OF THE WATER MANAGEMENT SYSTEM OF ANGKOR: A PROVISIONAL MODEL
}

\author{
Roland Fletcher ${ }^{1}$, Christophe Pottier ${ }^{2}$, Damian Evans ${ }^{1}$, Matti Kummu ${ }^{3}$ \\ ${ }^{1}$ Department of Archaeology, University of Sydney, ${ }^{2}$ EFEO Siem Reap, ${ }^{3}$ Finnish Environmental Institute and Helsinki University \\ Email: roland.fletcher@arts.usyd.edu.au \\ Keywords: Cambodia, Angkor, irrigation, GIS, water management
}

\begin{abstract}
The nature and even the existence of water management at Angkor has been the subject of considerable debate since the 1970s. Recent work at Angkor by the EFEO and the Greater Angkor Project has mapped a vast water management network extending across approximately $1000 \mathrm{sq} \mathrm{km}$. From the new map an outline can be provide of the development of the network between the $8^{\text {th }}-9^{\text {th }}$ and the $14^{\text {th }}$ centuries. Each large extension of the network tapped water from a succession of natural rivers flowing from NE to SW. Each river was further north and was tapped further to the west. The network had five major components - E-W embankments that trapped water flowing from the north and northeast; $N$-S channels that eventually delivered water to large reservoirs (baray); the baray and the large temple moats; embankments and channels oriented from NW to SE that could distribute water back from west to east across the slope of the land; and channels oriented towards the southwest which could dispose of water rapidly to the lake, the Tonle Sap. Significantly the later major channels, such as the Angkor Wat canal and the canal that pre-dated the current Siem Reap river, were drains that served to dispose of water into the lake.
\end{abstract}

\section{INTRODUCTION}

From the early 1990s Angkor has been mapped in two stages, first by the EFEO and then by the joint efforts of the Greater Angkor Project, an international collaboration between the University of Sydney, EFEO and the APSARA Authority which manages the Angkor World Heritage Site. The mapping from ground surveys and remote sensing has shown that the well-known group of great temples lies at the centre of a dispersed, low-density urban complex covering about a $1000 \mathrm{sq} \mathrm{km}$, containing a vast, linear network of embankments and channels (Fig. 1) (Pottier 1999; Evans 2002; Evans et al 2007; Fletcher et al. 2003). The urban complex extends far beyond the conventionally recognised central area of Angkor that is now delimited by the Heritage Park.

From north of Bantei Srei in the northeast and Nokor Pheas in the northwest, through the great baray or reser- voirs around Angkor Thom, and southwards to the shore of the Tonle Sap is an elaborate, interconnected water network. The network has three main sectors (Fig. 2), as identified by Kummu - a northern zone where water was spread out across the landscape and its flow rate could be reduced; a central zone around the temples where water was held in the baray; and a southern zone, between the centre of Angkor and the lake, where water was either disposed of rapidly to the lake or distributed slowly from west to east across the slope of the landscape (Evans and Kummu 2003)

The large scale, integrated perspective provided by the comprehensive remote sensing AIRSAR radar coverage has enabled us to move away from the conventional view of Angkor, readily identify the nature and overall operation of the water network in Angkor and also see it as a system of interconnected elements. Previously, the emphasis on the central area of Angkor has prevented a recognition of the crucial role of the northern half of Angkor and the function of the Great North canal and its subsidiaries. These are clearly visible on the 1994 radar image from the space shuttle Endeavour, which was commissioned by the World Monuments Fund. They were in part, mapped on the ZEMP GIS database (Engelhardt 1996) and are also partially represented on Claude Jacques map of Angkor in 1978. Focusing on the centre also diverts attention from the major channels that cross the southern half of Angkor and take or took water directly out to the lake. These have been partially noted since the 1960s and were systematically mapped by Pottier (1999) in the 1990s.

Since the 1980s and a seminal paper by Liere (1980) there has been a debate about the management of water at Angkor and the interpretation of the large water features such as the baray and the temple moats, in terms of varying degrees of ritual-functional dichotomy (Acker 1998, Stott 1992, Egawa 1999, Fukui 1999). This paper does not propose to review or discuss the content of that convoluted debate but instead intends to contribute towards a redefinition of the debate by presenting a new model of the development of the vast water management network that the work of the EFEO and the Greater Angkor Project has revealed. 


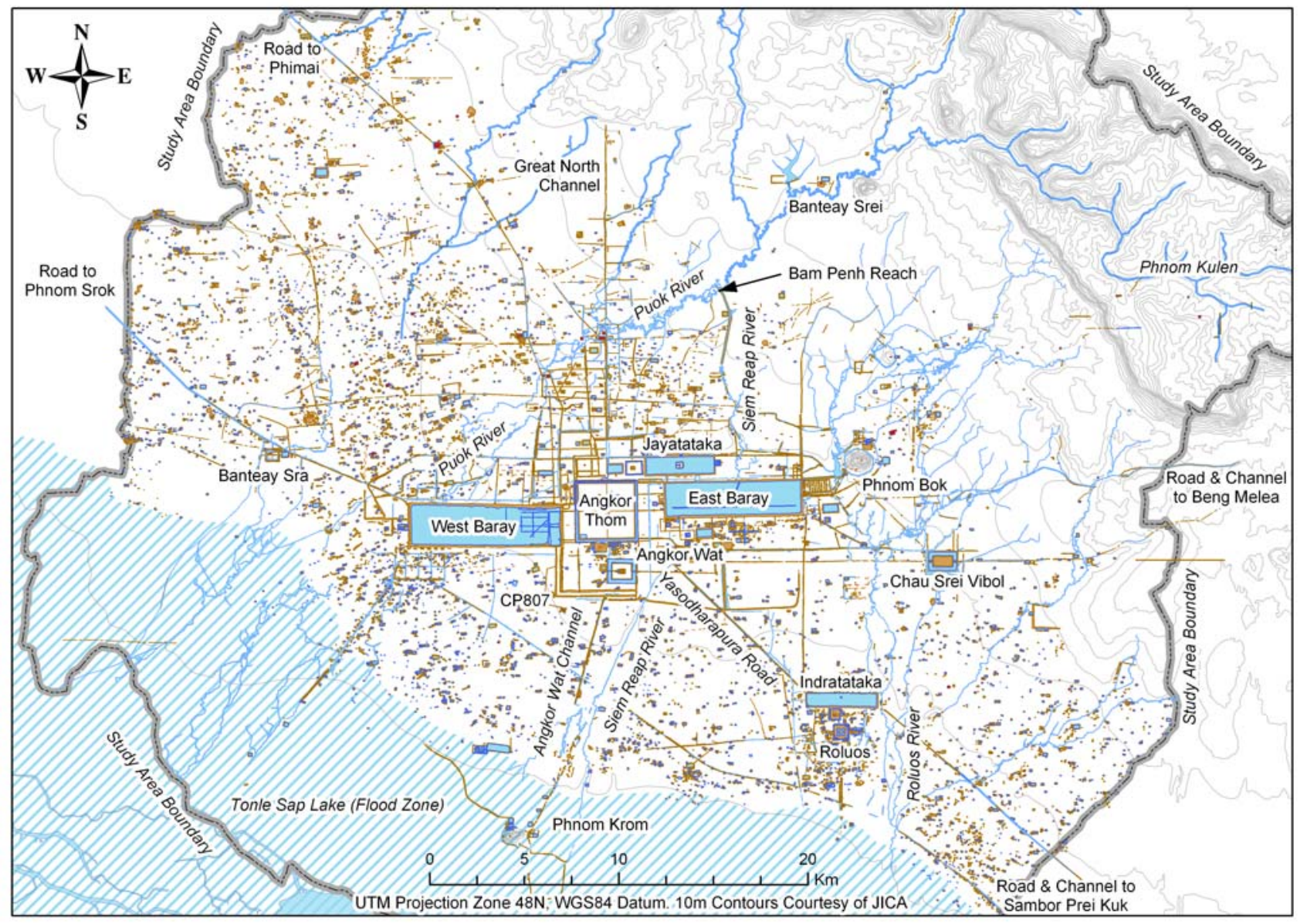

Figure 1. The Angkor dispersed, low-density urban complex (Evans and Pottier). Note 1: The new, provisional map of Greater Angkor has been prepared at the University of Sydney by Damian Evans, combining the radar data with the survey work of Christophe Pottier in a GIS database. Mapping of Angkor continues both by the EFEO and by the Greater Angkor Project (GAP).

\section{The Spatial Organisation of the Water Management Network}

Once the entire network from the lake to the hills is presented on a single map it is apparent that the great baray are the middle zone of a huge water management system (Fig. 2). The northern zone between the hills and the major baray is a collector and flow management system for spreading water across the landscape and also directing it southwards down major channels. These constructed channels, in essence canals, have right angle turns or cross-channels into which water could be shunted, slowing it down or speeding up its flow as required and removing suspended sediment. The northern part of the network would therefore have played a crucial role in slowing down and dispersing the monsoon water. From the network of embankments and channels the water could then move southwards either into bypass channels or into the baray.

The central zone of the network is the major baray and temple moats that were built from the $9^{\text {th }}$ to the $12^{\text {th }}$ century AD. These now appear to have been a set of massive water storage units fed by the northern collector system. While the East and West Mebon and the Neak Pean leave no doubt that the baray had a ritual meaning, the East Baray also has an inlet channel in its NE corner and a massive masonry lined outlet channel in the middle of its eastern bank; and the West Baray was a meticulous piece of engineering (Fletcher et al. 2003: Fig 6). There is an intake channel $25 \mathrm{~m}$ wide in its northeast corner, fed by canals from the north and east (Fig. 3). A channel also cuts through the southern portion of the east bank of the baray and another channel cuts across the SE corner of the baray to enter feature CP807 to the south. Further evidence of a precise function for the baray is the grid of channels south of the SW corner of the baray, identified by Pottier (2000a). The rectangle formed by the outermost channels of this feature has previously been misidentified as part of the boundary of a pre-Angkorean "city”, Bantei Choeu (e.g. see Higham 2001: 66). All of the baray are associated with linear channels and banks outside the northern and southern banks, leading in to the NE corners of the baray and also extending out from the eastern banks and to the south and southeast.

The southern zone of the network is a suite of disposal and distributor channels. The most obvious set is associated with the West Baray and consists of a channel running to the south-west - the shortest, steepest and therefore the quickest route to dispose of water into the lake; and also a channel to the south-east, the Southeast 


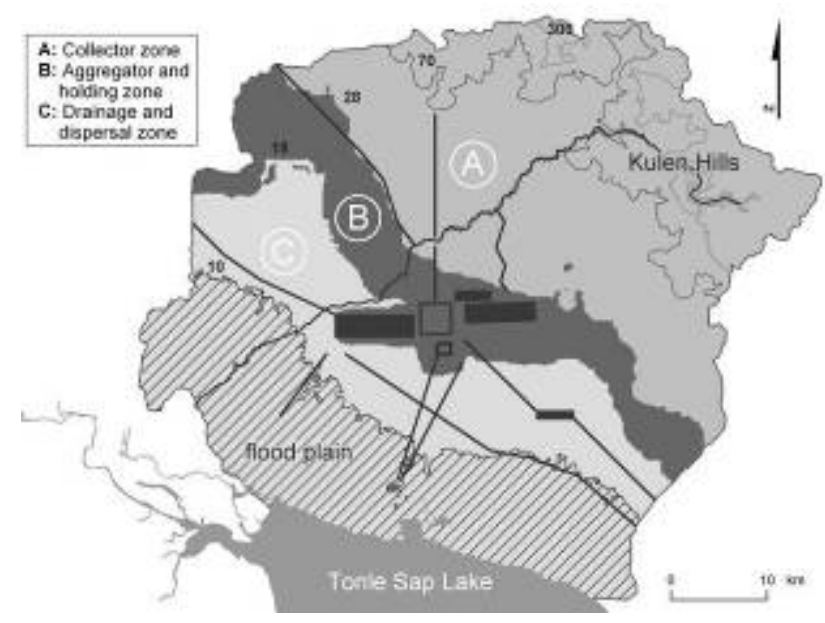

Figure 2. Tripartite water network (Kuтmu).

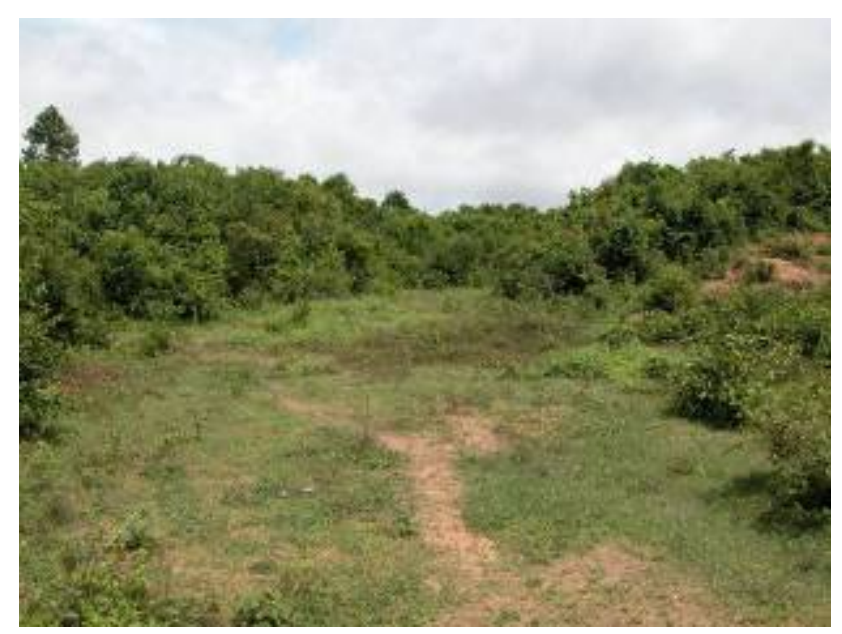

Figure 3. West Baray intake channel (Fletcher).

Canal/Road, that goes all the way to the south of Roluos andthen on to the Damdek "canal" and beyond. The SE $\mathrm{road} / \mathrm{channel}$ is almost the slowest route the water could take and still flow, suggesting that this was a distributor canal to spread water across all of the land south of the canal down to the dry season edge of the lake.

Another disposal canal ran from the vicinity of Angkor Wat down to Phnom Krom. The Siem Reap river may now follow part of the course of what may have been another former disposal canal from the East Baray down to the same terminus by Phnom Krom. South of Siem Reap town, where the Siem Reap river diverges to the east, the line of an abandoned channel is still visible as a row of occupation-mounds passing west of Vat Attvear and also by a buried channel that is exposed in crosssection in the ditch of the planned, new ring road at Kar Kranh. The channel was about 40 to $50 \mathrm{~m}$ wide and only $1-2 \mathrm{~m}$ deep. This channel is probably the original line of the post- $14^{\text {th }}$ century Siem Reap. Below it there is an earlier channel of unknown date (Fig. 4) that is perhaps of

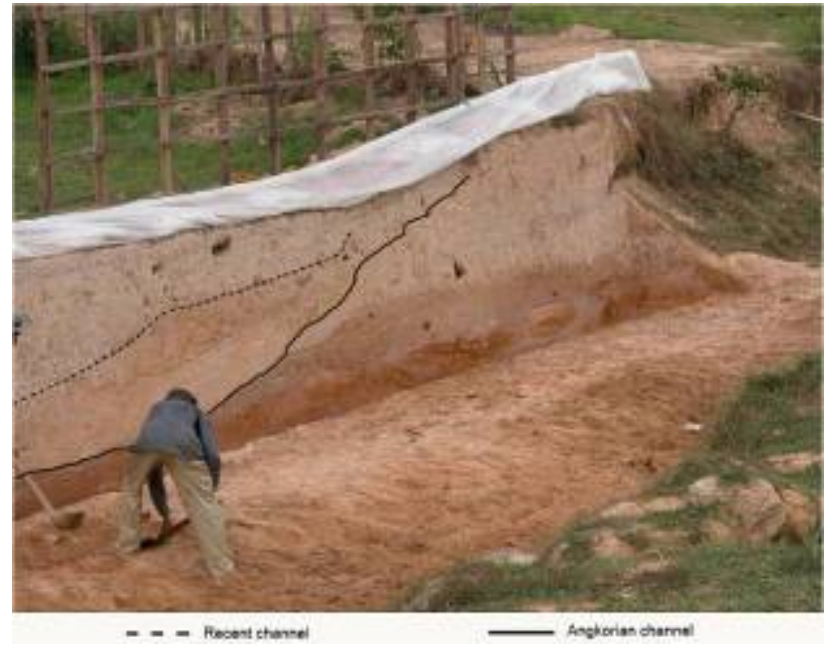

Figure 4. Eastern side of buried Angkorian channel (marked by black line). Probably the original line of the post- $14^{\text {th }}$ century Siem Reap channel. Below is an earlier channel of unknown date. Above is a recent channel (dashed line) (Fletcher).

some significance for a preceding form of the network (see below - East Baray Addition).

The Rolous group deserves further attention as it has a baray (the Indratataka) and also a major channel running due south to the lake that would have acted as a disposal channel. The village of Kompong Plok is located at the southern end of this channel. It also has what may be a distributor channel as well, previously interpreted just as a road. The linear embankment leading south-east from the centre of Angkor to the Indratataka and the Angkorian road running SE from the SE corner of that baray would have channelled water to the southeast in the same way as the SE canal/road that extends to the SE from the grid of channels near the south-west corner of the West Baray (see Pottier 1999: 120-3). In addition, a poorly preserved, and probably early channel runs westwards towards Vat Attvear. These appear to be elements of a whole early network around the Roluos group. If it had the same overall structure as the later networks around the East Baray and the West Baray there should also be remnants of a $9^{\text {th }}$ century AD collector system of E-W embankment to the north of Roluos.

\section{The Development Sequence of the Network}

The network has a complex and surprising history. A model of that development is outlined below (Figs 5-10) presenting the successive major components of the system. Broadly, the development began in the SE, spreading north and then west, with the last major additions from the early $12^{\text {th }}$ century onwards being back along the central axis of Angkor. These later additions

[Overleaf; Figs 5-10 represent a model of the development of the water network presenting the successive major components of the system (Fletcher \& Wilson)]. 


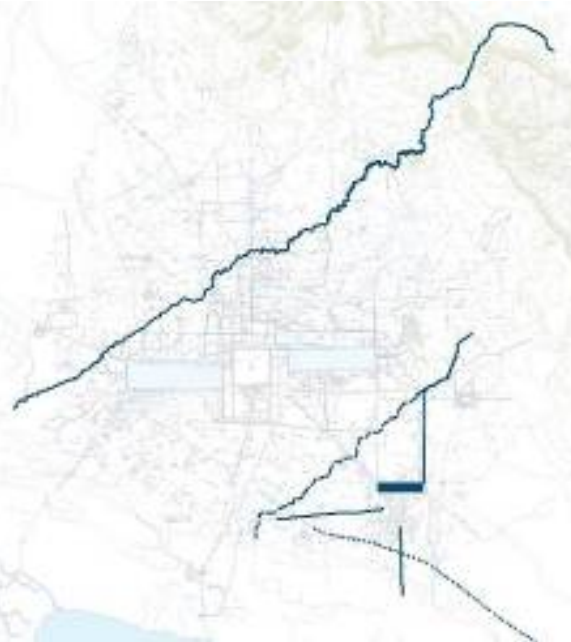

Figure 5. Roluos network.

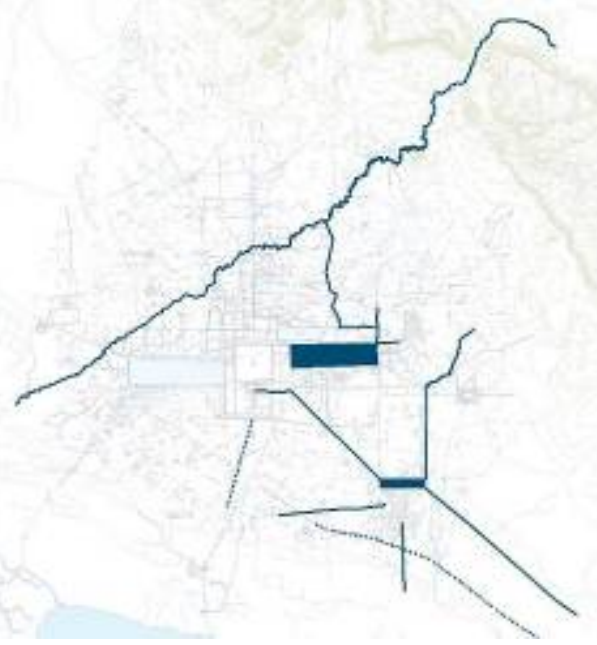

Figure 6. East Baray addition.

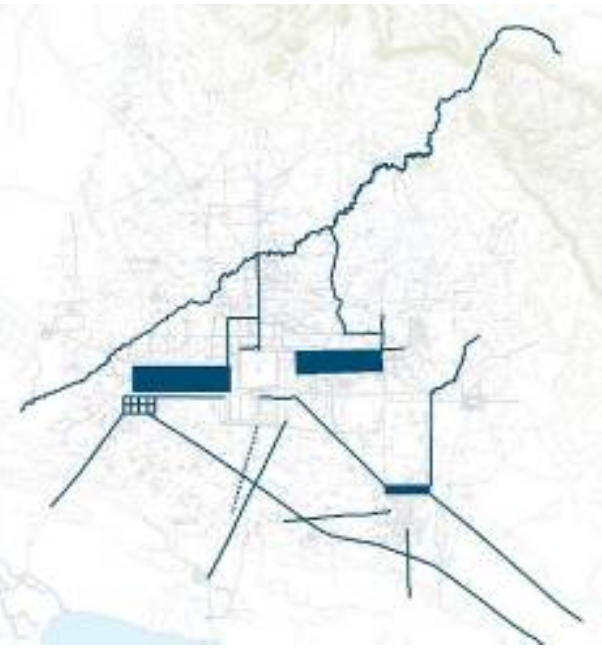

Figure 7. West Baray addition.

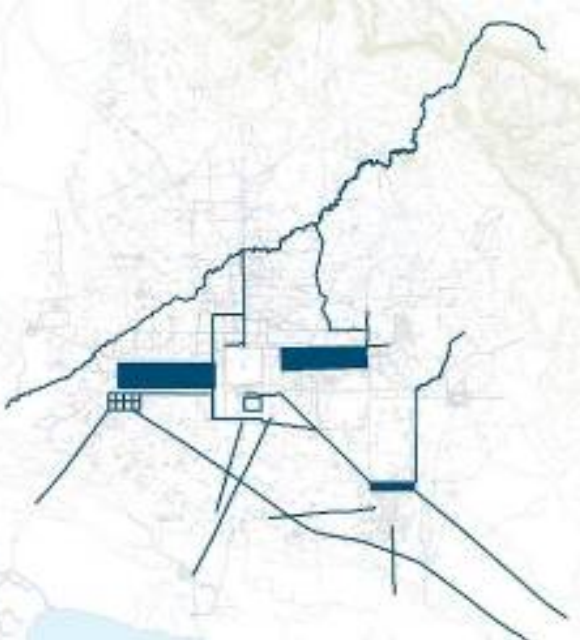

Figure 8. Angkor Wat addition.

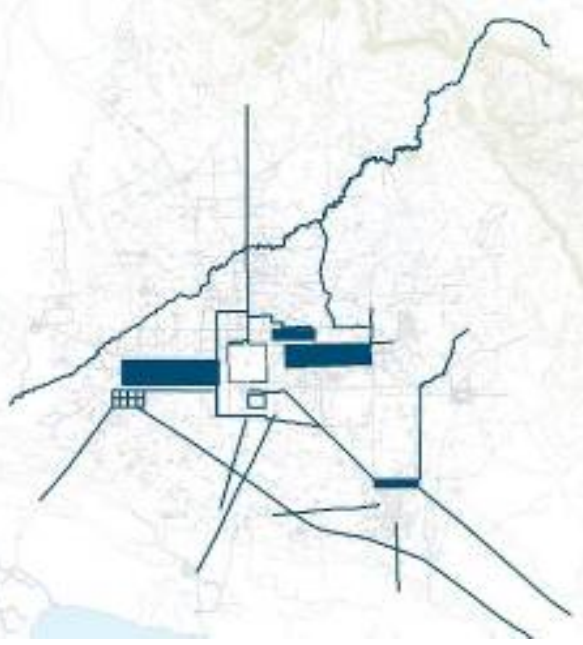

Figure 9. Jayatataka addition.

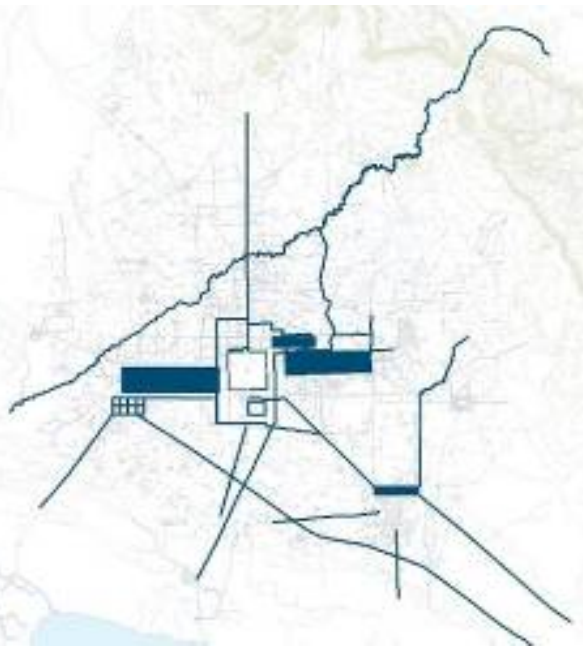

Figure 10. Siem Reap “river/canal” addition. 
include a disposal canal from Angkor Wat and finally the creation of the southern half of the canal that the Siem Reap river now partially follows southwards past Angkor Thom and down to the lake. The system appears to have developed closure, turning back in on itself from the 12th century onwards. Significantly the later canals down the middle of southern Angkor would have assisted primarily with disposing of water from the centre of the urban complex.

The overall sequence of the development of the network can be identified from a combination of the operational constraints created by each addition, the archaeological evidence of the relative and absolute dating of key components of the network and the long established historical chronology of the Angkorian rulers and the temples and constructions with which they were associated. Interpreting the development of the network and the connections between channels, moats and reservoirs depends upon the mechanical specifications that water flows downhill and that there has to be some gradient for water to flow. What happens upstream therefore directly affects what happens downstream. In addition, some downstream features could not have functioned unless there was an upstream component to deliver water to them. Because most of the components of the network were very ordinary embankments and channels that would not have done anything without an upstream connection, debates about "non-functional" uses that might have obviated such a necessary pattern do not arise. The order of the main additions to the network and how the major channels and basins were connected in space and time can be outlined. Key nodes in the network can be dated historically from inscriptions and we can recognise from remote sensing images and ground surveys that some features, such as channels, cut across others and are therefore later than the feature they cut. Together these sources limit the number of possible options for the overall order in which the major elements were added.

The proposed sequence only refers to the various major suites of features that make up the system. We do not, as yet, know the exact order in which every feature was added to the system or when all the features were modified. There are several lifetimes of research to be consumed in understanding the smaller additions and changes within each major addition to the network.

\section{Roluos network $8^{\text {th }}-9^{\text {th }}$ centuries (Fig. 5)}

The Roluos network as currently observable includes a baray, the Indratataka, various channels and moats around the Bakong, a major N-S canal to the south running to the lake and a canal to the west running in the direction of Vat Athvear. To supply the baray a canal would have been required to bring water from the north. The location of the obvious candidate would have lain along the track of the current Roluos river which now flows north-south in a slightly meandering channel. Just to the west of Chau Srei Vibol there is a marked change in the channel direction. The upper part of the Roluos, north of the road to Chau Srei Vibol, follows a NE to SW direction similar to the flow direction of the upper Siem Reap and the Puok river. The implication is that the lower Roluos is following the line of the old canal $\left(8^{\text {th }}-9^{\text {th }} \mathrm{C}\right.$ AD) that tapped water from the original Roluos river to the north. If this was the case then a hypothesized original river, like the Puok, may have flowed NE to SW, debouching to the lake somewhere between Wat Hepkha and Phnom Krom. On this configuration the western canal would have been a means to return diverted water to the hypothesized old river. On the eastern side of the baray, water taken round the north eastern corner or out of a now buried exit channel in the eastern bank would have been available for dispersal further to the SE down the line of what is now the embankment of the former Angkorian road embankment (now Route National 6). Whether this was an original part of the $8^{\text {th }}-9^{\text {th }} \mathrm{C}$ system around the Indratataka will only be revealed by excavation.

\section{East Baray addition (Fig. 6)}

In the late $9^{\text {th }}$ century the East Baray was added to the north of the Roluos network. The great N-S embankment that runs down to the NE corner of the baray would have diverted the flow of the NE-SW river, that lies north of Phnom Bok (Pottier 1999: 101-3). This river was either another channel running to the SW across the Angkor plain or was a northern tributary of the old Roluos river to the south. Finding out which it was is crucial to an eventual understanding of the relationship between the East Baray (Yasodharatataka) and the Indratataka. If the channel north of Phnom Bok was direct tributary of the Roluos then the East Baray was robbing the Indrataka of a significant proportion of its water. If, however, the East Baray tapped another, separate, river then that baray complimented rather than diminished the Indratataka. The alternatives will also be significant for interpreting the second stage diversion discussed below. The Roluos tributary model suggests that any future, additional water supply for the East Baray may have been created to allow more water to be returned to the Indratataka. Alternatively if the first stage diversion for the East Baray captured a separate river then an additional supply would suggest that either the original source was insufficient for cumulative use and/or the new offtake was a means to supply the East Baray and free more water to go back to the Indratataka. The geomorphology of the channels north of Phnom Bok is critical to an understanding of changing functions of the supply channels.

In the second stage of development, perhaps in the Rajendhravarman restoration of Angkor as the capital in the early $10^{\text {th }}$ century, a new offtake was created from the then-Puok river, even further to the north and west. This offtake (the later Siem Reap river) was a zig-zag canal aligned from N-S (Pottier 1999: 203-4). It came down as far as the great E-W bank that crosses the landscape to the north of the $12^{\text {th }}$ century Ta Som temple. This offtake then turned east to cut through the first stage N-S embankment to deliver water to the entry channel in the NE corner of the baray. There are several other channels that run from the "Siem Reap" offtake eastwards through the old first 
stage embankment. Their date of construction is unknown. They could either have been contemporary with the new offtake, in which case they would have offered additional options for moving water eastwards, or they could be later additions to try and cope with the downcutting that eventually occurred in the Siem Reap channel (pers.comm. Terry Lustig).

Water was taken out of the baray through the middle of the east bank by way of the massive masonry-lined channel of Krol Romeas (Dumarcay and Pottier 1993. Plate 1, Pottier 1999: 109-11). There may also have been a disposal canal from outside the SW corner of the baray (see below) but the path whereby water got to it is unknown. A possible route is along a canal south of the south bank, following the line of the açrama established by Yasovarman I (Pottier 2003). The configuration of the West Baray and its two southern channels to the SW and the SE suggests that the East Baray may originally have had two similar channels. The SE channel equivalent would be the Yashodharapura "road" that ran eastward from Phnom Bakheng and then turned SE to align with NE corner of the Indratataka. The SW channel equivalent would have followed the line either of the Angkor Wat canal or what is now the Siem Reap river. At Kra Kranh just south of Siem Reap town an earlier, deep channel was recognised below the post $14^{\text {th }}$ century sand-filled channel (see below Siem Reap addition). As yet we do not know whether this lower channel was natural or was deliberately constructed.

Since the second offtake for the East Baray was constructed that channel has progressively captured the water of the former Puok river. The decapitation of the Puok is of significance for the late history of the network (see below Siem Reap addition). The name "Siem Reap river" is now used for the entire channel from the Kulen, down the offtake, passing between Angkor Thom and the East Baray and then down to the lake. But the course of the river from the east side of the Jayatataka south to the lake does not appear to have existed until late in the history of Angkor. There is no evidence that the first offtake in the $10^{\text {th }}$ century went south of the line of the north bank of the Jayatataka. Nor was there a highly active channel in the east west space between the location of the Preah Khan/Jayatataka on the north and the East Baray and Angkor Thom on the south. At Tumnup Barang, just south of Preah Khan all the channel sediments are fine grained (Fletcher et al. 2003: 110). In addition, the massive E-W wall and embankment between the NE corner of Angkor Thom and the NW corner of the east Baray is not consistent with presence of a large river going to the south. Nor do the old N-S channels east of Thomanon and Chau Sei Tavoda suggest any substantial water flow. The implication is that the current line of the Siem Reap is a late addition.

\section{West Baray addition (Fig. 7)}

The West Baray is served by a second offtake from the Puok, the North Canal. At the present time the remnants of this canal commence at the Kror hills and run down to the north end of the north causeway of Angkor Thom. This, however, is probably not the early $11^{\text {th }}$ century configuration. The southernmost half kilometer is a later addition aligned precisely on the N-S axis of Angkor Thom and the portion of the North canal north of the Puok is separate from the part immediately to the south of the Puok (Fig. 11). That northern portion of the north canal may therefore be a later addition (see Jayatataka addition) added when the southern end was al;so modified to coincide with the north gate of Angkor Thom.

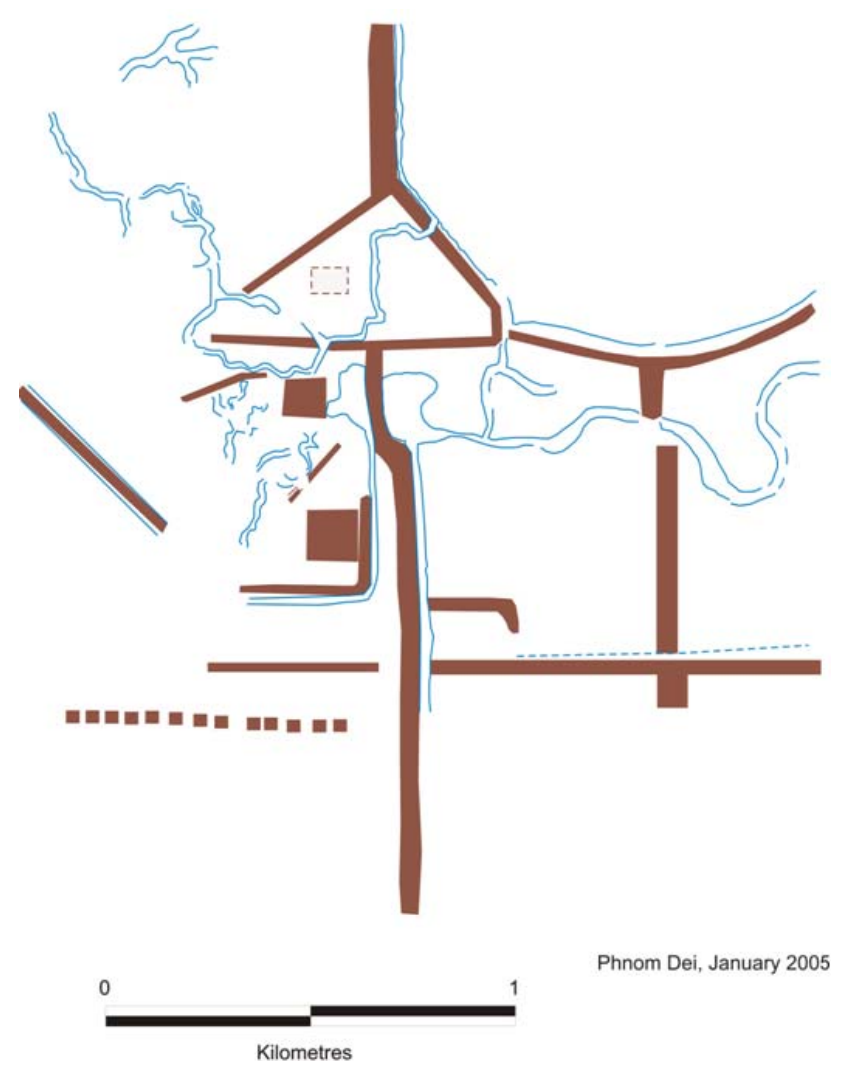

Figure 11. Junction of the two sectors of the Great North channel with the Puok river at Phnom Dei (Fletcher \& Pottier).

The $11^{\text {th }}$ century format required, at minimum, an offtake from the Puok and a suite of channels to bring the water to the NE corner of the baray through a series of right angle turns. There are also several other offtakes from the Puok west of the North Canal that run down towards the NE corner of the baray and connect to the NE inlet through several N-S and E-W channels. The date of these offtakes is uncertain but they presumably postdate the North Canal as they are further west. They would have served to capture any surplus water that remained in the Puok river after it passed the North Canal offtake and were therefore either to deal with episodic high river levels or a cumulative higher river flow or an attempt to extract as much water as possible from a decreasing water flow. Analysis of the deposits in the offtakes will be required to clarify the situation.

Once water reached the NE corner it could either have been taken into the baray and/or could have been taken 
along bypass channels on the north side of the West Baray. Once it reached the western end of the baray the path of the water is extremely complex and unclear. It is noticeable, however, that the SW corner channel grid projects to the west of the western bank of the baray suggesting that at some point in its history the grid could also have collected water from the north around the western end of the baray.

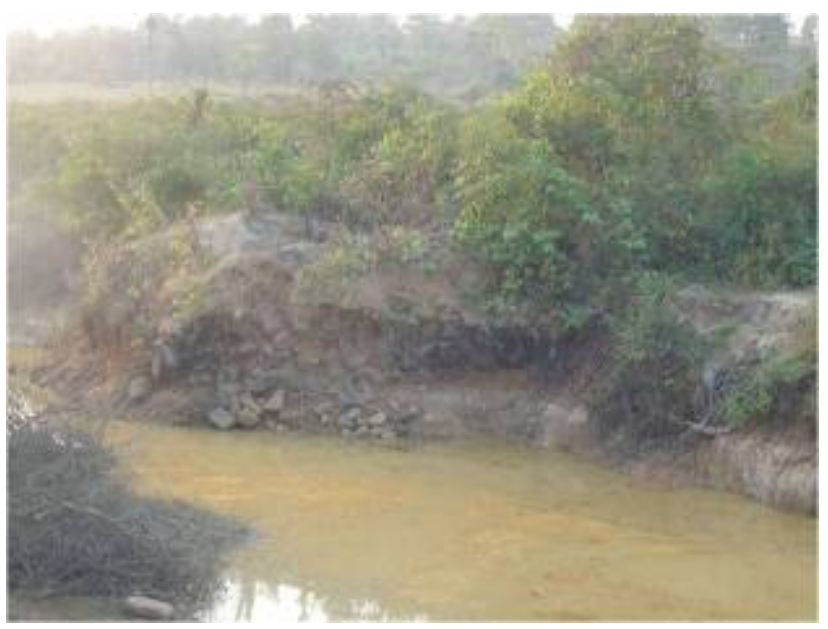

Figure 12. Massive masonry structure in the western face of the east bank of the West Baray (Fletcher).

At the eastern end of the West Baray there is an outlet channel in the southern part of the east bank. But it is not known whether this is the original outlet as there has been much remodelling of this eastern bank of the baray and it may not be displaying its original configuration. A massive masonry structure is observable on the western face of the east bank which may indicate an equivalent feature to Krol Romeas on the East Baray (Fig. 12). It is also important to note that the area east of the east bank was probably modified very drastically when Angkor Thom was built and would have removed any eastward exit channel equivalent to the one on the East Baray. In addition, the south-eastern sector outside the baray. has been subject to much change especially when the Angkor Wat additions occurred. This is relevant to the issue of the path that water took from the eastern bank exit around to the SW corner of the baray. Feature CP 807 has changed the topography of the SE corner, concealing whether water could originally have been taken around the SE corner and then westward along a canal just south of the baray to the SW corner canal grid. There are some indications that east-west channels ran along the southern side of the south bank of the baray (pers. comm. Terry Lustig), in association with the "bastions" found by Pottier (1999) (Fig. 13). From there the SW disposal channel goes directly to the lake from the grid of channel to the south of the SW corner of the baray (Pottier 1999: 120-3). The SW corner grid and the SE Canal/Road would have distributed the water eastwards towards the Damdek "canal". Excavation will be required in and around CP 807 to identify whether remnants of an E-W channel survive under its banks.

\section{Angkor Wat addition (Fig. 8)}

The Angkor Wat addition in the early to mid $12^{\text {th }}$ century appears to have had two stages. The first was the Angkor Wat moat itself and its associated NW corner inlet channel and SW corner exit channel. Coring by Christophe Pottier (pers.comm.) indicates that the exit/disposal channel that runs from the SW corner of the Angkor Wat moat down towards Phnom Krom, may predate feature CP 807 (Pottier 2000b). If this is the case then CP807 was the second stage of construction. Today there is a curved channel about $2 \mathrm{~m}$ deep that cuts through the outer part of the SE corner of the baray bank curving westward into the NE corner of CP807, suggesting that this was the path by which water was brought into CP807. But this may be a later arrangement contemporary with the modifications caused by the building of Angkor Thom and the two E-W banks that connect the east bank of the West Baray to the outer banks of the SW corner of the Angkor Thom moat. The earlier route for water from the original West Baray exit channel, would now lie under CP807.

CP807 provided a means to hold water in storage and also to take it southwards then east across the southern side of Angkor Wat. From there surplus water could have been diverted into the disposal channel and dumped into the lake near Phnom Krom. Water that was needed for further use would have flowed eastward into the southern portion of CP807. From there it was available to be directed down the eastern side of the Yasodharapura "road" to the northern side of the Indratataka and onwards to the east if needed for distribution over the area to the south.

\section{Jayatataka addition (Fig. 9)}

When the Jayatataka baray was added in the late 12th century the southern end of the North Canal was realigned to match the axis of Angkor Thom and a channel was built from the North Canal running eastwards through a series of right angle turns to an entry in the NE corner of the baray. The source of its water strongly suggests that the 10-12 km of the North Canal to the north of the Puok river was an addition to take water from streams flowing out of the Khror hills in order to supply the demand of the Jayatataka. But if this were the case then the Jayatataka would appear to have had a role in delivering water to somewhere else in Angkor. This function, however, is as yet very obscure.

There is no evidence of an outlet in the east bank of the baray, though Ta Som could perhaps be on or near the location of one. It is also unclear where any water taken off the east or around the south side of the baray would have gone as it could only flow into a channel running westwards from the middle of the north side of the north bank of the East Baray. Any flow westward would either have gone into the NE sector of the Angkor Thom moat or would have debouched ultimately into the channels that connect to the NE corner of the West Baray - a very circuitous and curious way of getting water from the North Canal to the West Baray via a temporary stay in the Jayatataka. The alternative is that the channels of Ang- 


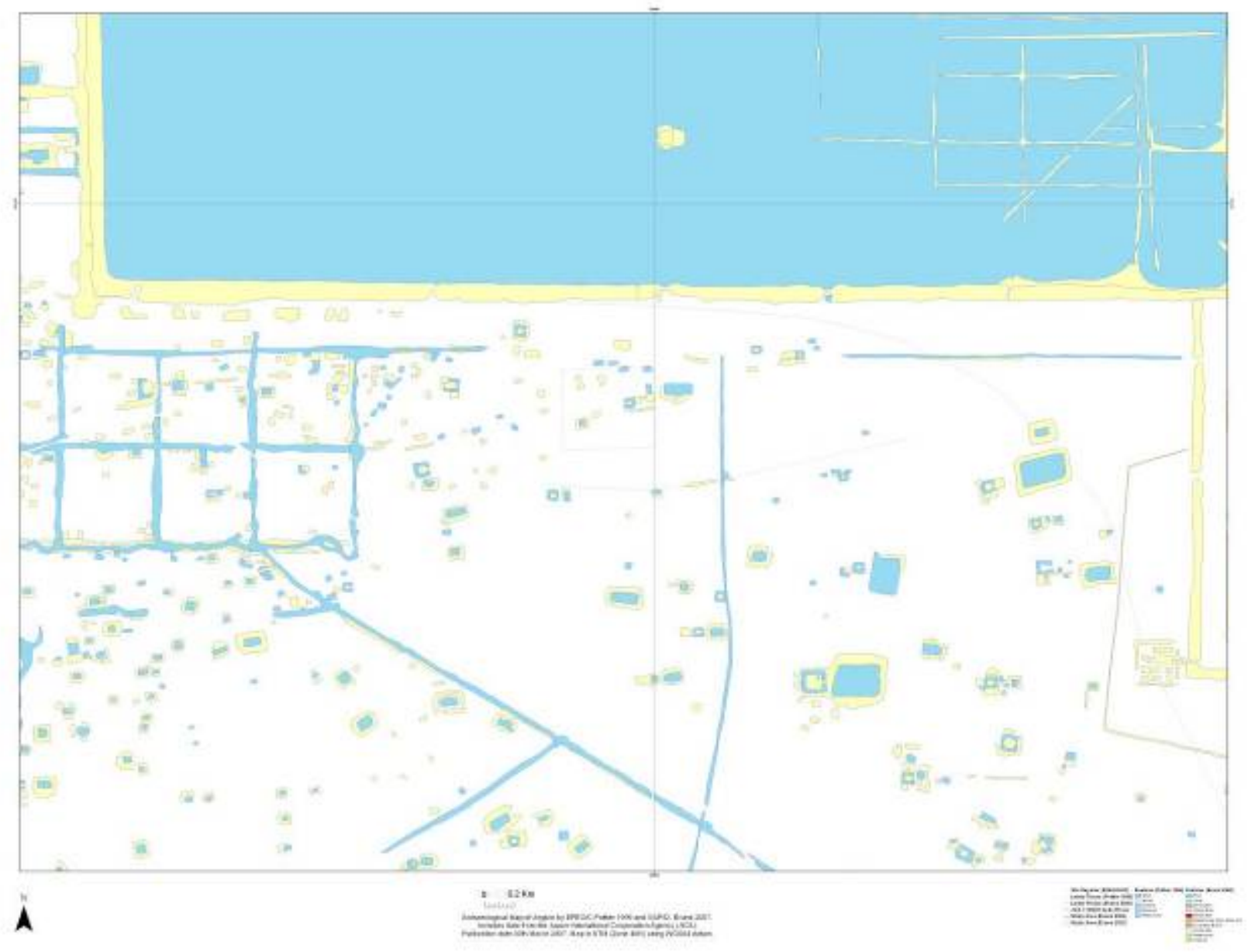

Figure 13. East-west channel along the southern side of the south bank of the West Baray (Evans \& Pottier).

kor Thom had the same kind of relationship to the Jayatataka as the SW grid had to the West Baray.

Another possibility is that the Jayatataka was only a representation of a baray and was perhaps only functioning as a holding basin and evaporation surface to cope with excess water from the North Canal. If this was the case then the argument for the addition of the northern part of the North Canal is problematic as its proposed role presumes an increased demand for water for the Jayatataka. This leaves the possibility that the Jayatataka was associated with the initial stage of opening a channel to the south through the barrier wall between Angkor Thom and the East Baray. Such a channel would have delivered water directly into the enclosure east of Angkor Thom and would also have offered an additional path to deliver water down the line of the Yasodharapura road. The Siem Reap canal would then also be its disposal channel. Given that the Jayatataka could have served both dipersal and disposal along that route we should reserve judgement on it having no useful function and instead focus on finding out whether or not it had an eastern exitway.

\section{Siem Reap "river/canal” addition (Fig. 10)}

The diversion of water eastwards through the Angkor Wat addition would only have been possible if the channel in which the Siem Reap river now runs was not present in the $12^{\text {th }}$ century. But there are indications at Khar Kran that even before the $14^{\text {th }}$ century vegetation deposit was laid down that substantial sand deposits were filling an old channel south of modern Siem Reap town. This suggests that a channel connecting northern and southern Angkor was already open by the $13^{\text {th }}$ century at the latest, since the amount of sand and the magnitude of water flow needed to move it could not have derived from a catchment south of Angkor Wat.

We do know that after the deposition of the $14^{\text {th }}$ century vegetation, presumably when the post $12^{\text {th }}$ century Splean Thma was built - the stone bridge over the Siem Reap east Angkor Thom (Fletcher et al 2003: 115-7) - a major channel was constructed running south through the barrier wall between Angkor Thom and the East Baray. That channel was the final full diversion of the Siem Reap and ran southwards all the way to the lake passing east of Phnom Krom. It was the last major addition or alteration to the overall network. A key issue to pursue is whether the line of this final canal follows the line of an old dispersal canal of the late $10^{\text {th }}$ century south of then East Baray. This is problematic because the Kar Kranh section shows that the channel immediately below the Siem Reap channel was completely buried before the final, straight 
dispersal canal was built. The sand deposits which predate that final canal and the coarse sand which completely fills it, suggest that rapid water flow was already occurring in the southern half of Angkor prior to the $14^{\text {th }}$ century and eventually overwhelmed the last great canal of Angkor. That the canal was built apparently to dispose of water rapidly, not to conserve and distribute it may be indicative of some of the changes and stresses that the network was facing through the $14^{\text {th }}, 15^{\text {th }}$ and $16^{\text {th }}$ centuries CE.

\section{Review of the development process}

The development of the water management network of Angkor proceeded by partially decapitating a succession of rivers further and further to the north and west, capturing flow off the Kulen and Khror hills, then sending it southwards and back eastwards instead of to the southwest. The great baray and great temple moats were then a mechanism to allow that water to either be shunted along channels almost as far back to the south east as the location of its northern source or to be dumped promptly into the lake. The network offered many alternative paths and provided a versatile and flexible means to manage immense and seasonally variable quantities of water. The great embankments in southern Angkor that run from NW to SE appear to be critical to the system. In principle they would allow water to be distributed across the entire landscape to the south of the embankment. That would require either a lifting device like a simple shaduf to allow water to be transferred to small channels south of the embankments or else is required temporary breaches through the bank to release water to the south. As there are no known illustrations of an Angkorian shaduf-like device the latter seems to be a necessary condition. Such breaches should be apparent to excavation and such a use of the embankments should have made human occupation relatively sparse along them.

The restructuring of the network that began with the building of Angkor Wat and continued though to the $14^{\text {th }}$ century has drastically modified several parts of the southern distribution and disposal channels. This has been especially marked to the south of the East Baray where archaeological excavation will be necessary to test the proposed model of a $9^{\text {th }}-10^{\text {th }}$ century disposal channel extending from the area to the south west of the SW corner of the baray. If the East Baray had an ancestral version of the great grid of channels that lies southwest of the SW corner of the West Baray, then the late 12th Ta Prohm sits on top of part of it. In addition the complex network of channels to the south of Bantei Kdei, which has been known since 1900-1910, begins to look like a substantially modified complex arrangement for moving water east and west and across to the Yashodharapura road from Phnom Bakheng to the Indratataka. As yet the line of that "road" has not been traced from the point were it would have turned westwards to proceed on its E-W alignment to Phnom Bakheng. The proposed development sequence and the key role that it indicates for embankments that traverse the landscape from NW to SE suggests that the bend in the Yashodhapura "road" may hold the key to the way in which water was moved southwards from the East Baray in the initial configuration of the system.

Having identified the overall pattern of development of the water network we can now begin to focus on the vexatious question of what the water network was used for. Two obvious functions can be envisaged, flood control and irrigation. Both require us to understand how the water was moved, where and at what rates. The issue is amenable to archaeological enquiry because the processes and their outcomes will have left physical indicators such as filled breaches through embankments, changes in the particle sizes of successive layers of deposition and sloping or disturbed strata. We no longer need to envisage competing claims that remain hypotheticals.

\section{CONCLUSIONS}

The extensive area survey of Angkor by the EFEO and by the Greater Angkor Project illustrates how a comprehensive and consistent data collection procedure can help to clarify the approach to a major interpretative issue. A water management network with three distinct interconnected operational zones for control, storage and distribution has been identified. The old debate about whether or not there was a functional water management network in Angkor that could have assisted flood control and irrigation is at an end, replaced, fortunately, by further developing issues about the role of system, its development and its relationship to the demise of Angkor.

The magnitude of the features that make up the network relates to the use of sand with a small admixture of clay as a means to control water - a remarkable feat of engineering. The vast scale and extreme stability of the infrastructure is an intriguing corollary of its technology and might itself help to explain how the continuity and order of Khmer society endured despite the inherent instability of the medieval Khmer state prior to the $13^{\text {th }}$ century. How the network was managed and the degree to which the state ever participated directly in its day-to-day operation is a key issue and may itself be central to what eventually happened to Angkor. There are indications that the network had developed into an involuted system but one that was both generating stresses due to its inertia and may also have been facing external changes as well. If this was the case then Angkor faced a serious conundrum because the massive stability of its infrastructure was somehow both implicated in the changes and cumulatively unable to deal with them. The last additions to the network from the $12^{\text {th }}$ century onwards increasingly served to dispose of water rather than to hold and distribute it. The potentially serious implication is that from the $12^{\text {th }}$ century onwards Angkor was, perhaps, having to cope with and try to manage increased water flow from the northern catchments.

\section{ACKNOWLEDGEMENTS}

Many thanks to the staff of APSARA Authority, who are members of the GAP field teams. In the field we have had an invaluable collaboration with Heng Than, Khieu Chan, Tous Somaneath, Chai Ratchna, Chea Sarith, Chourn 
Bunnath, Ea Darith, Chai Visoth and Srun Tech - especial thanks for many long, hard days on research. I am also indebted to the APSARA staff who manage the administration for the project in Cambodia, for their participation, advice and help. Thanks also to the many University of Sydney members of the Greater Angkor Project and the international volunteers who work with the project each year. In Sydney special thanks to Martin King for his varied, hectic and vital assistance.

My particular thanks to Dan Penny, Mike Barbetti and Christophe Pottier of EFEO, and Ros Borath, the Director of the Department of Monuments and Archaeology, who are the current co-directors of the Greater Angkor Project; and to Damian Evans the current deputy director. My appreciation and thanks also to Ang Choulean, the Head of the former Department of Research and Culture and his deputy Im Sokrithy for their work with the project.

For technical assistance and advice my thanks to JPL and Horizon Geosciences, AINSE, Concept Aviation, and the various agencies and departments of the University of Sydney, specifically the College of Science and Technology, and the College of Humanities and Social Sciences, the Faculty of Arts and the School of Philosophical and Historical Inquiry. The encouragement offered by the Cambodian government and the support of the Australian embassy is much appreciated. The Greater Angkor Project is supported by grants from the Australian Research Council and ANSTO/AINSE. I am indebted to Amansara for the time as Scholar-in-Residence which made possible the completion of this paper.

\section{REFERENCES}

Acker R. 1998. New geographical tests of the hydraulic thesis at Angkor. South East Asia Research 6: 5-47.

Dumarçay J. and C., Pottier 1993. Documents Topographiques de la Conservation des Monuments d'Angkor. Paris: École française d'Extrême-Orient.

Egawa Y. 1999. Newly acquired topographical maps for the Angkor Archaeological Area and an interpretation of the ancient infrastructure. Renaissance Culturelle Cambodge 16: 293-319.

Engelhardt R.A. 1996. New directions for archaeological research on the Angkor Plain: the use of remote sensing technology for research into ancient Khmer environmental engineering. Bulletin of the Indo-Pacific Prehistory Association 14: 151-60.
Evans D. 2002. Pixels, Ponds and People: Urban Form at Angkor from Radar Imaging. Unpublished BA (Hons) Thesis. Department of Archaeology: University of Sydney.

Evans D. and M. Kummu. 2003. Modelling Cultural and Natural Hydrology Using Radar Imaging at Angkor. ICGRHWE conference, Three Gorges Dam, China, September 16-19 2003.

Evans, D., C. Pottier, R. Fletcher, S. Hensley, I. Tapley, A. Milne and M. Barbetti 2007. A comprehensive archaeological map of the world's largest pre-industrial settlement complex at Angkor, Cambodia. Proceedings of the National Academy of Sciences of the United States of America. Vol. 104 no. 36, pp. 14277-14282.

Fletcher R.J. and C. Pottier. 2002. The Gossamer City - a new enquiry, Museum International 54: 23-27.

Fletcher R.J. et al. 2003. Redefining Angkor: structure and environment in the largest, low density urban complex of the pre-industrial world. UDAYA 4: 107-21.

Fletcher R.J. 2004. Materiality, space, time and outcome. In J.R. Bintliff (ed.), The Blackwell Companion to Archaeology, pp. 110-40. Oxford: Blackwell.

Fukui H. 1999. Groslier's hydraulic society theory of Angkor in the eyes of an agroecologist. Southeast Asian Studies 36(4): 546-54.

Higham C. 2001. The Civilization of Angkor. London: Weidenfeld and Nicholson.

Jacques C. and M. Freeman. 1997. Angkor: Cities and Temples. London: Thames and Hudson.

Liere W.J. van 1980. Traditional water management in the lower Mekong Basin. World Archaeology 11: 265-80.

Pottier C. 1999. Carte Archéologique de la Région d’Angkor. Zone Sud. Ph.D thesis, 3 vols. Universite Paris III Sorbonne Nouvelle (UFR Orient et Monde Arabe).

Pottier C. 2000a. Some evidence of an inter-relationship between hydraulic features and rice field patterns at Angkor during ancient times. Journal of Sophia Asian Studies 18: 99-119.

Pottier C. 2000b. À la recherche de Goloupura. Bulletin de l'École française d' Extrême-Orient 1:79-107

Pottier C. 2003. About Yaçovarman's Buddhist açrama in Angkor. In P. Pichard and F. Lagirarde (éd.), The Buddhist Monastery: A Cross-Cultural Survey, pp. 199-208. Paris: EFEO

Stott P. 1992. Angkor: shifting the hydraulic paradigm. In J. Rigg (ed.), The Gift of Water, pp: 47-58. London: School of Oriental and African Studies. 